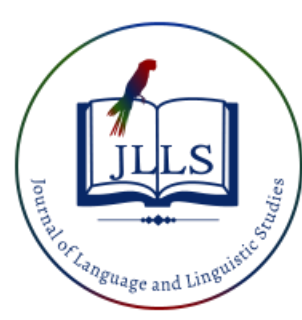

Available online at www.jlls.org AND LINGUISTIC STUDIES

ISSN: 1305-578X

Journal of Language and Linguistic Studies, 17(3), 1484-1497; 2021

\title{
The cultural view of North Bali community towards Ngidih marriage reflected
}

\author{
from its lexicons
}

\author{
I Gede Budasi a $^{\text {ID }, ~ I ~ W a y a n ~ S u r y a s a ~}{ }^{\text {b }}$ iD \\ ${ }^{a}$ Universitas Pendidikan Ganesha, Bali, Indonesia \\ ${ }^{b}$ ITB STIKOM Bali, Denpasar, Indonesia \\ APA Citation:

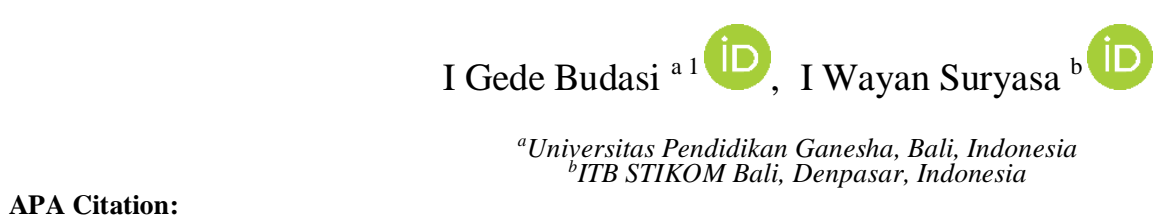

Budasi, I. G., Suryasa, I.W. (2021). The cultural view of North Bali community towards Ngidih marriage reflected from its lexicons. Journal of Language and Linguistic Studies, 17(3), 1484-1497. Doi: 10.52462/j1ls.107

Submission Date:05/05/2021

Acceptance Date:10/08/2021

\begin{abstract}
This study aimed at finding the answer to the question: How does the culture view of the North Bali Community look as seen from the lexicons used in their ngidih marriage tradition?. Conducted in North Bali, this study was designed based on descriptive qualitative research with an ethnolinguistic perspective. The results showed that the whole ritual steps of the ngidih marriage consist of ngluku, mesedek, ngidih, mebiakala, natab kesurya, melukat pebersihan, malehpeh, natab sayut, and ngaturang piuning. Sixty-two lexicons were found in this study. Among them, 11 were categorized into nouns, 49 as verbs of action, and two as adjectives. Spreading over the whole steps of the marriage, all of the lexicons reflect the uniqueness of the community's cultural meanings, that is, the bond of the bridegroom and bride in a marriage is not only a matter of physical and spiritual union but it is also a binding with their cultural attachment, which include the rule of bridegroom's family, clan, traditional community, local government, and the marriage. The marriage is viewed to be complete one only if it has passed sets of rituals which are witnessed by three parties; bhuta saksi (evil spirits witness), manusia saksi (human beings witness), and dewa saksi (God witness) based on Bali Hindu religion.
\end{abstract}

Keywords: lexicons; ethnolinguistic perspective; "ngidih" marriage tradition

\section{Introduction}

Language and culture cannot be separated. Both of them influence and complete each other. Language is a means of maintaining culture (Hestiyana, 2017). A culture will be intelligible and respected by its users if they can understand the language that is used to convey that culture (Nirwani, 2018). It is indicated that language is not only an aspect of culture but is also a means to document it. Hence, language has a crucial role and has to be developed and maintained since a lost language will also make the culture of a community disappear, as has been experienced by the Balinese community in North Bali (Wamalwa and Oluoch, 2013). Bali Island has developed into one of the world's most visited tourist destinations, with over one million foreign visitors flying directly to Bali (Budasi \& Anggayana, 2019). Bali has been known as the tourism destination in the world (Anggayana, Budasi, \& Kusuma, 2019).

\footnotetext{
1 Corresponding author.

E-mail address: gede.budasi@undiksha.ac.id
} 
Language, something that lives and develops, will always undergo changes and shifts following the development of time (Mbete, 2007). Evidence of language changes and shifts that are very obvious and can be seen in lexicons of the language (Crowly, 1997). The changes and shifts also occur in the Balinese language spoken in the area mentioned above. It can attract foreign come to North Bali. Lots of foreign tourists visit every holiday and every day (Anggayana, Budasi, \& Kusuma, 2019). The visit included tourists' curiosity in several aspects, namely: culture, tradition, rituals, daily activities of Balinese, scenery, culinary, and history of previous royal relics has made the attraction of tourists in general (Anggayana, Budasi, \& Kusuma, 2019).

The preliminary observation in the area shows a tendency of a decrease in the use of the Balinese language (Bahasa Bali) by its speakers, especially by the young generation. It is the preservation of language and culture with its variety (Anggayana, Suparwa, Dhanawaty, \& Budasi, 2020). It is indicated by the fact that more and more lexicons in this language have vanished in its ordinary language use. In this context, the lexicons that have undergone much decrease are those used in the ngidih traditional marriage. Based on the researchers' preliminary observation, few youths in the area are familiar with the lexicons used in the ngidih marriage tradition. If the condition is continually ignored without any effort to maintain and preserve it, the community will one-day lose a valuable legacy, self-identity, and identity as cultured members of community (Austine 2001, in Wamalwa and Oluoch, 2013). With the consideration of maintaining the lexicons mentioned above, there is a need to investigate the lexicons. The study aimed at identifying lexicons and reminding the local community of lexicons used in the ngidih. By finding out the related lexicons, the community will help maintain the existing culture of the village (Kramsch, 1998). It is as relic information to know. Therefore, the development of tourism in Indonesia often requires services for certain information (Sudipa, Aryati, Susanta, \& Anggayana, 2020). Then, technology will form a new culture in which media saves creative potential for this research (Kusuma, Osin, \& Anggabawa, 2019).

Two previous studies on ngidih wedding in North Bali were done at least by two researchers. The first study was done by Arniati (2013) and the other done by Sudiartini (2018). Both these studies only focused on the identification of the communication strategies used in the ngidih wedding ceremony. The first study was done in Sawan village, and the other in Lokapaksa village. Thus, so far, no research focusing on the cultural (Toti, U.S., \& Majed, O.A. 2021) meaning of the marriage ceremony reflected in the related lexicons has been done.

Based on the explanation above, such a study is not only critical, but it should be done urgently. Therefore, the question to be answered in this study is: How does the culture view of the North Bali Community look as seen from the lexicons used in their ngidih marriage tradition?

\section{Theoretical Background}

As a theoretical background, some related theories, which include the relationship between language and culture, lexicons, ethnolinguistics, the systems, and types of marriage in Indonesia, are reviewed in this section.

\subsection{The Relation between Language and Culture}

Language is one of the cultural assets of every community and is a precious legacy that is passed on from generation to generation. Sapir-Worf in Casson (1981) maintains that the contents of each culture can be expressed in its language. Sapir-Worf in Casson, (1981) states that language has a relationship with culture. Culture is determined by language since language is an indicator of the latter. One cannot understand language and evaluate culture without understanding both of them. Language is beneficial and guides one to learn about the culture of a community. In line with Sapir-Whorf in 
Wierzbicka (1992), it can firmly be stated that thinking cannot be transferred from one language to another language since it is very dependent on the language used to formulate the thoughts. Hence, language is a means of thinking which, at the same time, bridges thought and culture. It means that the thinking pattern and cultural behavior of an ethnic group are inseparable from language (register, diction, stress, etc.) used by certain speakers of a language.

Culture reflects the characteristics or identity of a person. It is also inseparable from the language that is used in that culture. Culture will even die if there is no language. It means that it is inevitable that language and culture constitute a cluster. In other words, language and culture are two systems that are mutually attached to human beings. Culture is a system that regulates human interactions in society, whereas language is a system that functions as the means to make interactions happen (Masinambouw, 1997). Therefore, this close relationship applies because the culture is a system that regulates human interactions, while language is a system that functions as a means to make the system work. Hence, language is an instrument of culture or a realization of culture that is used by human beings to communicate, both through writing speech or movement (sign language), intending to express intensions to the interlocutor. It is in line with the view that to describe a culture is the same as to describe a language (Duranti, 1997). Through language, human beings can adjust themselves to the custom, behavior, and etiquette, and at the same time, can easily integrate themselves into a community. It aimed to preserve the local culture which exists in the society (Ratminingsih, Budasi, \& Kurnia, 2020). Lexicons in a language that are used to describe the culture reflect cultural meaning, like the social meaning of the language speakers. What is a lexicon? It will be explained in the section.

\subsection{Lexicon}

A lexicon can be defined as vocabulary, a simple dictionary, a list of terms in a field arranged alphabetically and completed with information, a component of language that contains all information about meanings and uses of words in language or wealth of words that the language has (KBBI, 2012:345). According to Chaer (2007), the word "lexicon" came from Ancient Greek. The word "lexicon" means "word", "expression" or "speaking program". According to Chaer this word is related to the words "lexemes", "lexicography", "lexicography", "lexical". It is also explained that "a lexical unit," is a meaningful linguistic unit. If lexicon is taken to be the same as vocabulary or a repertoire of words, then: "lexeme" can be called "word" (Nirwani, 2018). In this connection, Purwadarminta (in Suhenda et al. (2014:300) sees "lexicon" as an expression that contains certain meanings in the realms of knowledge, occupation, or art). Hence, a lexicon is a list of words that contain information about meaning and uses of words in a language. In linguistics, the lexicon is a collection of lexemes in a language. This term comes from the Greek word lexikón, which means 'word matter'. The study of lexicon covers what is meant by a word, structuring of vocabulary items, uses and storage of words, vocabulary learning, history and evolution of words (etymology), inter-lexical relations, and the process of word formation in a language (http://id.wikipedia.org/wiki/Leksikon). Based on the theories presented above, the meaning of the "lexicon" in this study can be understood, as stated by Chaer (2007), and cultural meanings are seen from the religious and cultural values, as stated by Winarsih (2015).

\subsection{Ethnolinguistics}

Ethnolinguistics is a branch of linguistics. It is concerned with linguistic dimensions (word, phrase, clause, and other linguistic units) in the social and cultural dimensions (such as ceremony, ritual, cultural events, folklore, etc.) at a wider scope to promote and maintain cultural and social practices in the community (Abdullah, 2013:10). It is a science that investigates matters related to a variety of 
language uses and cultural patterns (Sudaryanto, 1996: 7). In the ethnolinguistic perspective, there is a relationship between language and the world view of its speakers. It is similar to what is stated by Riana (2003: 8), who sees language as a cultural phenomenon whose study is in the form of language in culture, or language, and culture.

Furthermore, Kridalaksana (2011:52) sees ethnolinguistics as; 1) the branch of linguistics that investigates the relationship between language and a village community or a community who has not got a writing system. Kridaaksana calls it anthropological linguistics. The branch of anthropological linguistics that investigates the relationship between language and linguists' attitudes towards language. Mbete (2007) names it as cultural linguistics. These analyze language choices, ways, and thinking patterns of language use, ritual language, and the creation of advertisement discourse that is based on the local language. In brief, ethnolinguistics is the branch of linguistics that focuses on matters related to the relationship between the language and culture of a community or that studies language in use by speakers of a speech community.

The use of language in a community can be observed from the social and cultural dimensions, like rituals, cultural events, folklore, etc. The objects of the study can be in the form of the lexicon, descriptions of its characteristics, and descriptions of grammar and local languages that contain meanings or concepts that are given to a linguistic form (Chaer and Agustina, 2010). The meanings are formed based on the relationship between the communication symbol and the user's intellect and object (Vardiansyah, 2004:70-71). The meaning that is related to the lexicon as the tool of communication is a social phenomenon. Meaning covers more than just an individual's interpretation or understanding. It always covers many understandings, aspects of understandings that are collectively shared by the communicators.

\subsection{System and Types of Marriage in Indonesia}

Indonesian society has various kinship systems and forms of marriage, as well as provisions of inheritance systems. In a traditional marriage in every ethnic group in this country, married couples have to follow the tradition that prevails in their community truly. Based on Indonesian National Law, Act RI No. 1 of 1974, marriage is a physical and spiritual tie between a man and a woman as husband and wife. It aimed to form a family based on the one and only God. Hence, marriage has to be done and directed based on the customary law of the couple (Abdullah, 2013).

Almost all ethnic groups in Indonesia have traditions to pay a dowry (belis) if a man wants to marry a woman. In general, a dowry is understood as the giving of something by the man's family to the woman's family at a wedding. Dowries in many places are also understood as compensation to the woman's parents for the hard work done in bringing up the woman (Bora and Purwati, 2018). The submission of a dowry means that the woman has left her parent's clan and follows her husband's. The form and amount of dowry vary depending on the law and regulation stipulated by their custom. In Sumba, East Nusa Tenggara, Indonesia, the dowry can be in the form of buffalos or horses. In North Bali, it is generally in the form of 500-600 kilograms of rice. In former times, in Sawan district, Buleleng regency, North Bali, the dowry could be in the form of crops, gold, or cash (Darta, 2013).

The marriage system in Indonesia may follow patrilineal or matrilineal practices (Ariani, 1983). In the patrilineal principle, the kinship relation is directed from the father's line or the male line. In the matrilineal one, the reverse is true. In the patrilineal marriage system, the birth of a son is considered important because it is related to the inheritance of house, heirlooms, land, and leadership.

Every ethnic group in Indonesia has its marriage system. For example, West Sumbnese ethniques practice marriage system, which includes 1) deke teirum mawini (a marriage which has been decided by the parents from both sides from the time when the couple was in childhood). In North Lombok, the 
community has three marriage systems; 1) tepedait (a matched marriage based of an agreement between the parents of both parties; 2) melakoq (a type of marriage initiated by a proposal from the man's side, and; 3) memulang (an elopement marriage which is usually based on mutual love between bride and groom) (Muhammad, 2018). In the Balinese community, there are five marriage systems, namely 1) jodohange, 2) merangkat, 3) mlegandang (forced marriage), 4) nyentana, and 5) ngidih (Aryani,1983; Darta, 2013).

Darta also adds that Jodohange, a matched marriage, is between a bridegroom and a bride who come from the same clan in Bali. That kind of marriage does not base on love but the desire of parents who want this type of marriage to occur. Merangkat can be defined as kidnapping or abducting a girl to be married by her boyfriend. Merangkat married does not mean to steal by force or without the willingness of the girl, but the girl is kidnapped based on mutual love. Balinese choose this married type if the girl's parents do not agree with the married relationship. The merangkat marriage tradition can be understood as proof of the man's loyalty to his girlfriend. Melegandang, forced marriage, was very popular in Bali before the 1950s. Nyentana is a marriage in which a family does not have any boys to continue the male line of the family. Therefore the family invites a boy from another family to marry their daughter. Ngidih marriage is system requires a boy and his parents to propose a girl in front of her parents. Three questions are to be answered in this article include; how does the process of ngidih marriage take place; what lexicons occur in every stage of the process; and what the cultural meanings found in the related lexicons.

\section{Research Method}

This case study was conducted in North Bali. Advancement of the tourism industry, the majority of the people of this area work in the industry and leave the region especially in the Southern part of Bali. The lexicons related to ngidih marriage are rarely practiced by the young people in North Bali. Therefore, there is a tendency that these lexicons get extinguished in the future.The study was designed in a descriptive qualitative method. Interview, observation, and document analysis were selected as the method of data collection (Denzin and Lincoln (2011) in Meleong, 2013). The researchers acted as the main instrument in this study. The other instruments are interview guide, observation sheet, and fieldnotes a recording. Three informants of the study were selected based on a set of criteria which were determined beforehand. The collected data were analyzed qualitatively and reduced using abstraction, that is, by making a summary of the main points, the process, and statements that needed to be kept to be included. The next step was to arrange them in units categorized in the next step. Final step analysis data was to examine the validity of the data, and after that, the data interpretation started. The last procedure was concluding the study.

\section{Results and Discussion}

\subsection{Results}

Based on the objective and the obtained data analysis of the study, this study showed that the culture of the North Bali Community seen from the lexicons used in their ngidih marriage tradition can be presented in Table 1 and Table 2 below.

\subsubsection{Ngidih Marriage Traditional System in Balinese Ethnic in North Bali Community}

Ngidih marriage is one of the three marriage systems: jodohange (atepange), merangkat, and ngidih marriage, practiced in North Bali community. Being popularly used by the community members, it is a marriage by the proposal, that is, it requires the family of the bridegroom to propose to 
the candidate of the bride's family. There are some steps to be followed. The steps of ngidih marriage can be seen in Table 1.

Table 1. The Steps in Ngidih Marriage Traditional System

\begin{tabular}{|l|l|}
\hline Steps & Description \\
\hline Ngluku & $\begin{array}{l}\text { The bridegroom's family representative visits the parents of the bride to check } \\
\text { whether or not the bride candidate is really love the bridegroom. }\end{array}$ \\
\hline Mesedek & $\begin{array}{l}\text { The visit of the bridegroom's family representative to the parents of the bride to } \\
\text { inform the exact date when the wedding ceremonial process will be hold. }\end{array}$ \\
\hline Ngidih & $\begin{array}{l}\text { The ceremonial process of ngidih wedding both in the traditional house of } \\
\text { bridegroom and bride families. }\end{array}$ \\
\hline Mebiakala & $\begin{array}{l}\text { The process of symbolic purification of the spirit of the bride and bridegroom by } \\
\text { using fire and water soon after the bride arrives in the bridegroom's house. }\end{array}$ \\
\hline Natab kesurya & $\begin{array}{l}\text { A ritual of asking permision to God that the family of the bridegroom to hold } \\
\text { ngidih wedding ceremony }\end{array}$ \\
\hline Melukat pebersihan & $\begin{array}{l}\text { Melukat pebersihan is one in the symbolic ritual to purify the sperm (kama petak) } \\
\text { and the ovum (kama bank) of the couple. }\end{array}$ \\
\hline Malehpeh & $\begin{array}{l}\text { Malehpeh is a series of marriage rituals conducted in the bride's house where the } \\
\text { gift giving process is done. }\end{array}$ \\
\hline Natab sayut & $\begin{array}{l}\text { Natab sayut is the ritual conducted at the bridegroom's house to unify the } \\
\text { bridegroom and the bride spiritually as member of the bridegroom's clan. }\end{array}$ \\
\hline Ngaturang piuning & $\begin{array}{l}\text { Ngaturan piuning is a ritual to formalise the bride as the new member of } \\
\text { bridegroom family. }\end{array}$ \\
\hline
\end{tabular}

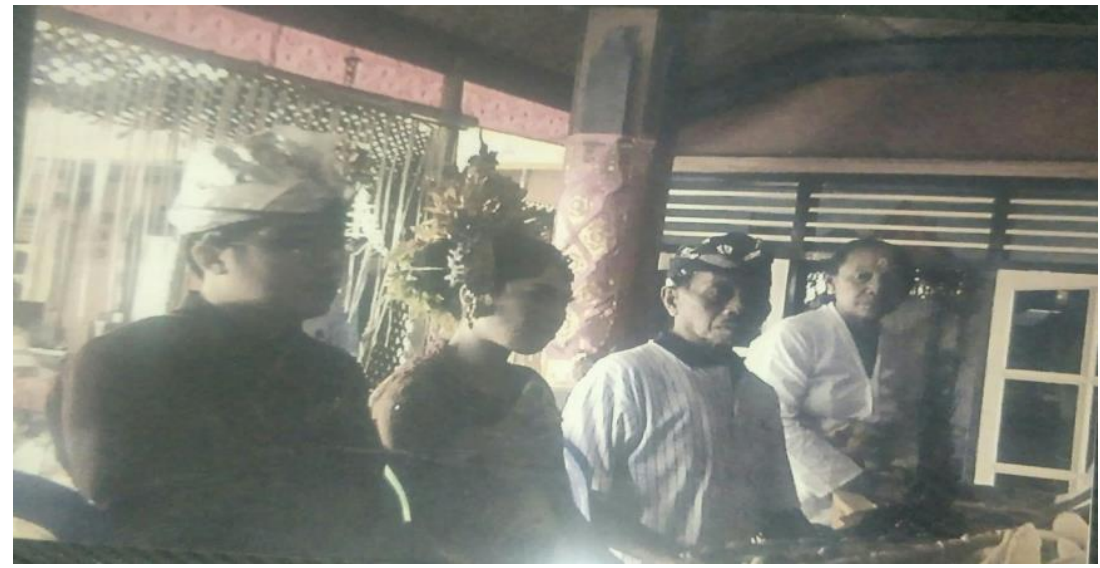

Figure 1. Ngluku

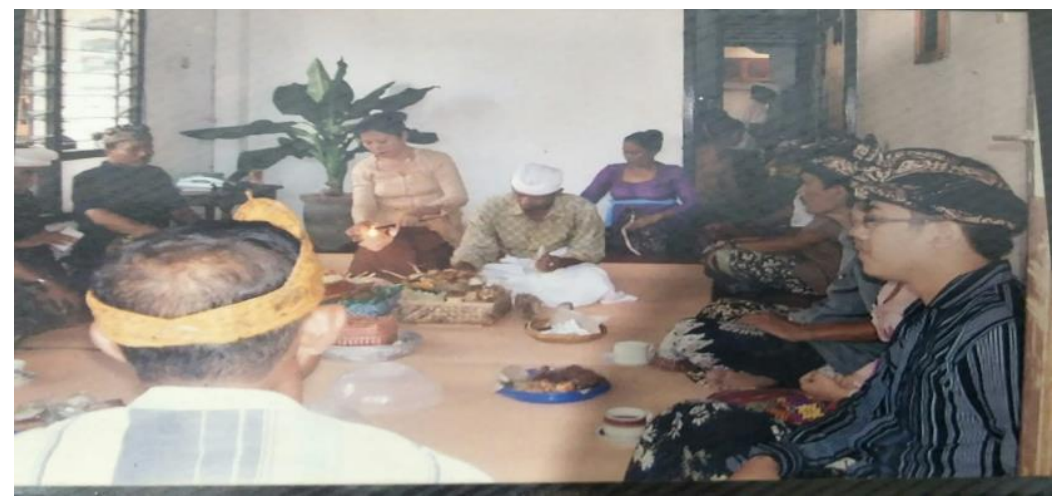

Figure 2. Mesedek 


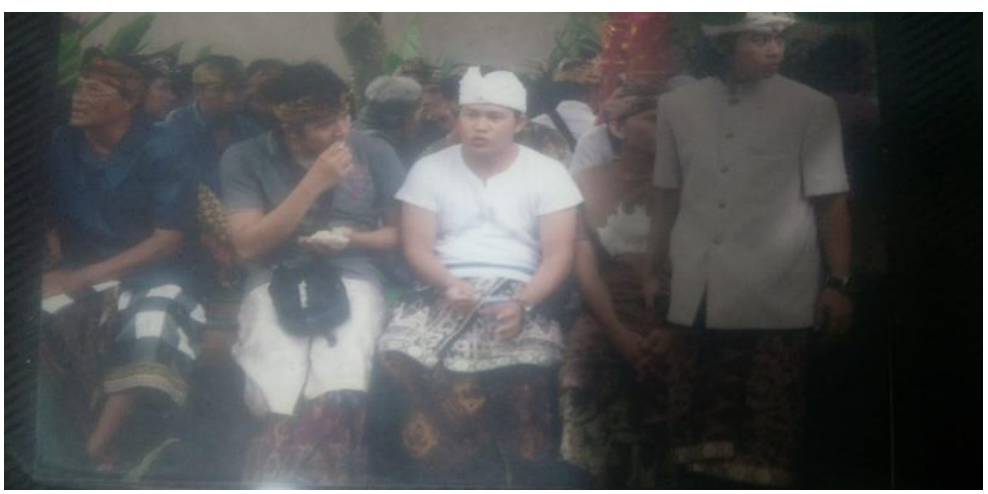

Figure 3. Ngidih

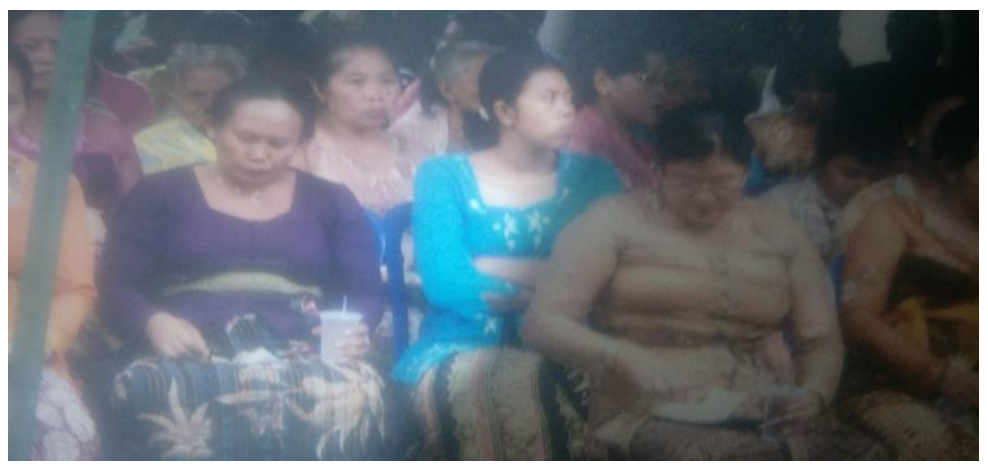

Figure 4. Ngidih

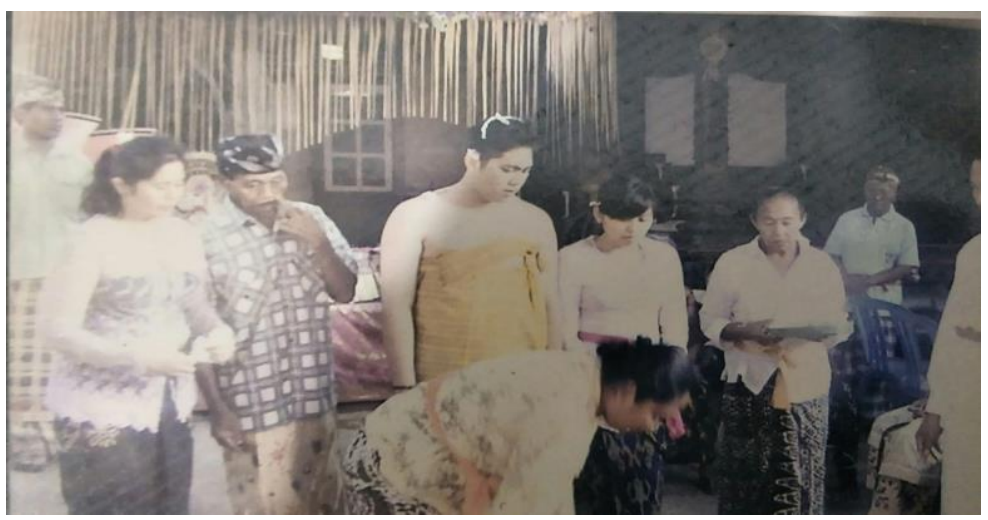

Figure 5. Mebiakala

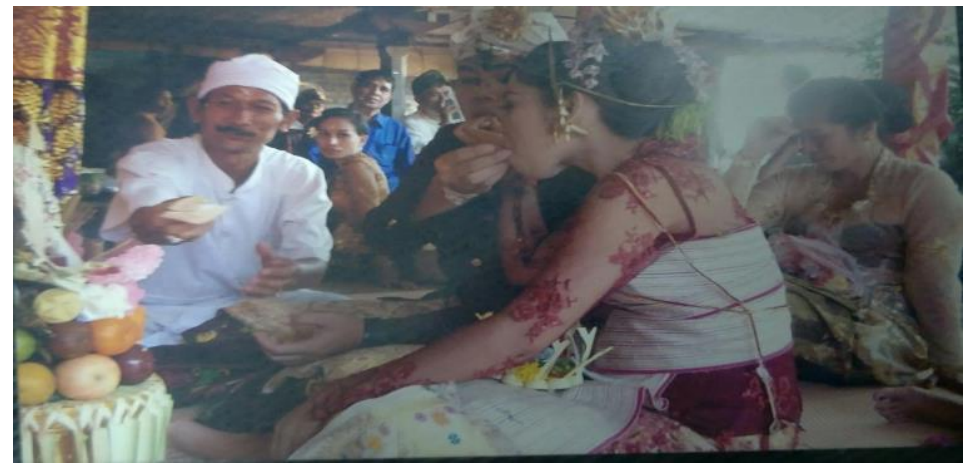

Figure 6. Natab kesurya 


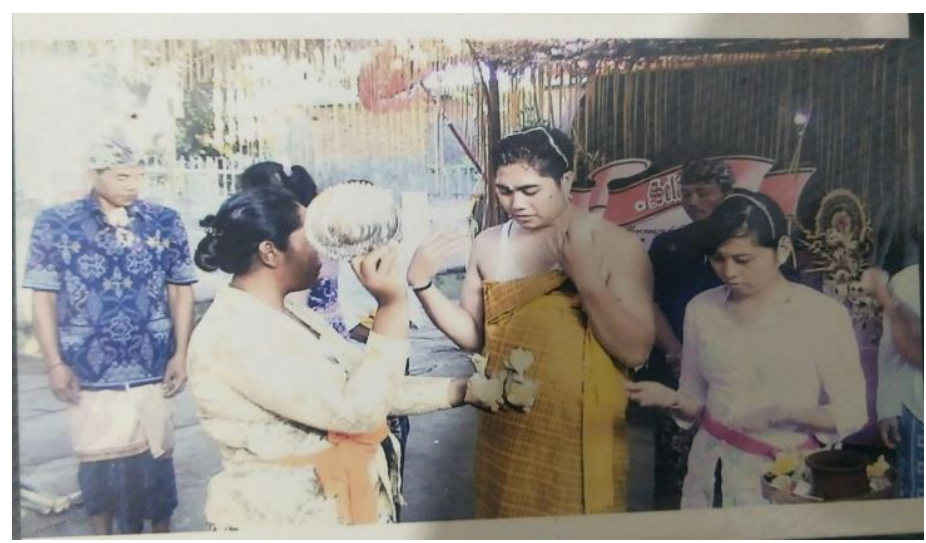

Figure 7. Melukat pebersihan

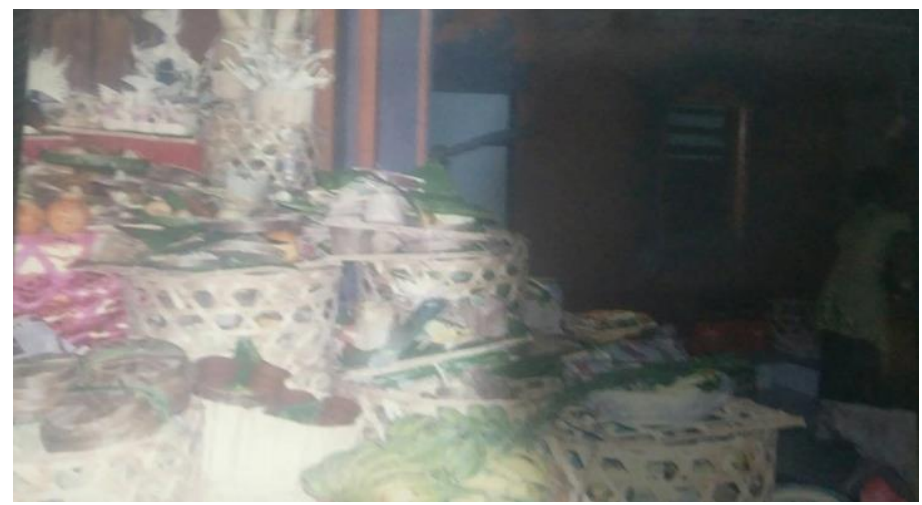

Figure 8. Malehpeh

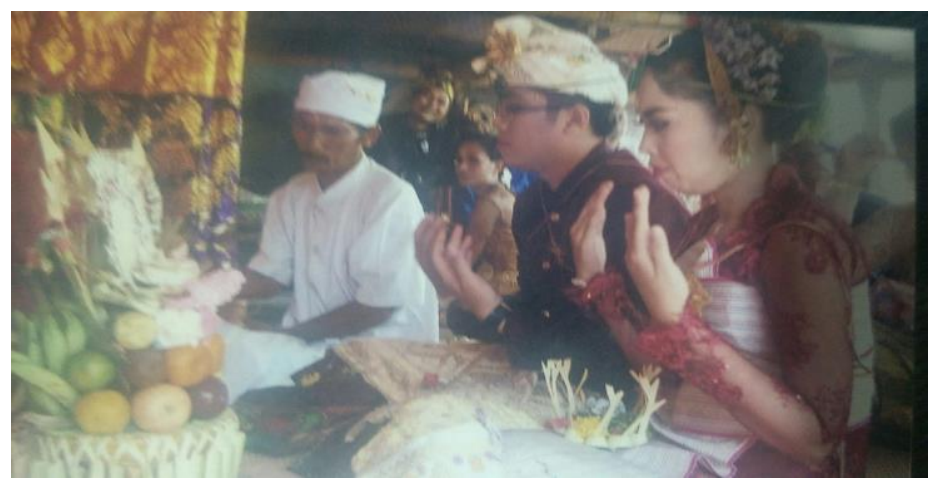

Figure 9. Natab sayut

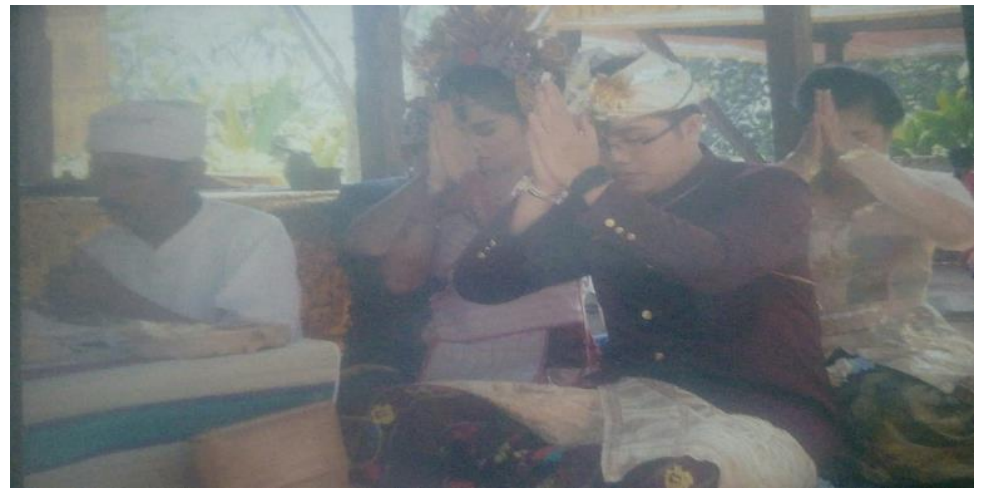

Figure 10. Ngaturang piuning 
Every step mentioned in Table 1 involves a local priest and family members of the intended couple, and some of the steps involve village government officials and tetua adat (the traditional community heads) as well as different kinds of rituals that should be followed. If they do not follow the steps, the community considers that the bride does not yet spiritually belong to the bridegroom's family, even if she has given birth and has grandchildren. In former times, her descendants were regarded as having a low status and did not have the right to inherit from the man's family. Thus, all marriage types should take the stages of rituals. It is the form of confirmation of their recognition both by the traditional community and the government. Nowadays, if the steps have not been completed, then their marriage certificate will not be issued.

\subsubsection{The Forms of Lexicons Used in Ngidih Marriage Tradition}

Based on the results of data analysis, there are 62 lexicons used in the steps of the ngidih marriage tradition. All lexicons are presented in Table 2.

Table 2. The Forms of Lexicons Used in Ngidih Marriage Tradition

\begin{tabular}{|l|l|l|}
\hline Forms & Lexicons & Frequency \\
\hline Nouns & pemangku, kubayan, pejati, pengerawos, nyuh, taluh, tinggkih, peselan, ajuman & 49 \\
& putih, ajuman kuning, kelanan, peras, tumpeng, canang pinunasan, pengeluar \\
& nasi warna, upasaksi, tri sakti, buta saksi, manusa saksi, dewa saksi, banten \\
& penyambutan semara ratih, banten seetan, kama petak, kama bang, betara \\
& $\begin{array}{l}\text { surya, wiwit, larapan pamelehpehan, pejati pengerawos, nasi pewarangan, } \\
\text { pecanangan, sirih, pinang, pamor, tembako, gambir, bantal alem, tetua adat, } \\
\\
\text { keliha dadia, pemangku dadia, tridasasakti, sanggah, daksina, tegteg, sang kala } \\
\text { petak, sang kale ireng, sang kala bank, sang kala jenar, sang kala brumbun, } \\
\text { canang penunasan, and bale gede }\end{array}$ & \\
\hline Verbs & $\begin{array}{l}\text { meluku, ngidih, mesedek, ngeregedin, mabiakawom, melukat pebersihan, } \\
\text { mesemareratih, natab sayut, natab ke surya, ngatunga piuninana, and tolak bala. }\end{array}$ & 11 \\
\hline Adjectives & reged and enteg. & 2 \\
\hline Total & & 62 \\
\hline
\end{tabular}

Table 2 shows the list of the lexicons used in the ngidih marriage ceremony which is connected to the steps in Table 1. The following is the explanation of the steps and their related lexicons:

Ngeluku is a meeting between the representative of the prospective bridegroom's parents and carried out in the prospective bride's house. The meeting is initiated by the prospective bridegroom's family and prospective bride's family (at least 2-4 persons from each party). The bridegroom's family informally come to tell the bride's parents that in three days, they will return to express their intention to propose to the prospective bride. This meeting does not include any local government officials.

Mesedek is a meeting between the representatives of the prospective bridegroom and bride. This lexicon takes place in the bride's house and is attended by the bridegroom's core family. The purpose of the meeting is to check whether the prospective bride agrees to marry the groom based on true love. If she confirms that she loves the bridegroom, the rest of the wedding steps and their rituals will be continued.

Mapiyeh is a ritual done in front of the gate of the prospective bridegroom's house at the time of first entering the house after the mesedek ritual. This ritual aims at symbolically cleansing the physical bodies and spirits of the couple by using fire (apitakepan) in dry coconut fibers and water (yeh) sprinkled by using a cedok (a scoop) made of a coconut shell. It is hoped that the couple is free from dirt (reged) and spiritual disturbances that may enter their bodies (ngeregedin) in the journey from the bride's house to the bridegroom's house. Thus, they can both conduct the marriage ritual later comfortably and peacefully. 
Biakawon is a ritual activity conducted in the bridegroom's house. The aim is to ask for witnesses (upasaksi) from butha kala, which is believed to be one of the three witnesses (bhuta saksi, manusia aksi, and Dewa saksi) that have to present and determine the legitimacy of the marriage. The media in this ritual consist of banten seetan and penyambutan semara ratih.

Melukat pebersihan is one in the series of activities in the biakawon ritual, which has as its aim purification of the sperm (kama petak) and the ovum (kama bank) of the couple. Both are believed to be the embryo of an offspring after the marriage ritual is conducted. The community member take the view that if the two things are free of dirt in terms of spiritual meaning, then a wise child will be born.

Mesemare ratih is one of a series of activities or a continuation of the mekalakalaan ritual. The aim is to spiritually unify the physical bodies and the spirits of the bridegroom and bride in the hope that the marriage will be blessed by the one and only God in His manifestations as Sang Hyang Semara and Sahyang Ratih.

Natab ke Surya is one of the activities done after passing the mabiyakala ritual and melukat for purification activity at the bridegroom's house. It involves praying to the one and only God for safety in His manifestation as Dewa Matahari (Sun God), and His willingness to become a spiritual witness to a smooth marriage that is to be conducted in the bride's house as part of manusia saksi and Dewa saksi.

Malehpeh is a series of marriage rituals conducted in the bride's house as the continuation of the mekalakalaan or mebyakaon ritual. In addition to their core and extended family members, the important persons who also come are the traditional and local government, the spiritual leaders from both parties. In this village, whatever marriage system is followed, the couple has to do the malehpeh traditional ritual process.

Rarapan is a set of offerings from the bridegroom's family that is brought to the bride's house as a ritual medium in the malehpehan ritual comprises nasi pewarangan, pecanangan, bantal alem, pejati pengerawos. In addition to pejati pengerawos, they also bring banten pejati to complete the number of gifts based on the agreement between the two parties. Usually, this pejati is given to the religious village leader (tetua adat), the head of the clan (kelian dadya), and the family temple priest (pemangku dadia).

Pejati pengerawos is a medium used by the spiritual leader appointed as the leader of the malelehpeh ritual. The aim is to pray for safety to Sang Hyang Trio Dasa Sakasi (eleven Gods as the manifestations of the One and Only God). Each of them is believed to occupy one of all the directions in the universe: east, west, north, south, southeast, southwest, northwest, East West, the center, top, and bottom. Through this ritual, positive energy from all of these directions is expected to come to energize the malehpeh ritual.

Pecanangan is the ritual medium in the opening of the malehpeh ritual. This medium is in the form of a betel nut (sirih pinang) completed with lime, tobacco, and gambier. Before the conversation starts in the malehpeh ritual, the senior persons (tetua) and other important persons who are present will be offered sirih pinang, and together, they will eat them. Sirih pinang is believed to have the ability to ward off evil spirits that may accompany or follow the presence of the malehpeh participants in the journey from their houses to the place where the malehpeh ritual is performed. The aim is to ask the one and only God in His manifestation as Vishnu (symbolized by betel), Iswara (symbolized by fruit), Bayu (symbolized by tobacco), Shiva (symbolized by lime), and Brahma (symbolized by gambier) for His willingness to cleanse dirty bodies, minds, words and actions in the malehpeh ritual.

Nasi pewarangan is a gift of food brought by the bridegroom's family at the time the malehpeh ritual is held. This food is in the form of plain rice, roasted chicken, and salt eaten by the bride and bridegroom, who feed it to each other. This activity takes place after the human witness conversation. 
Consuming the gift together symbolizes that they are starting to build a new family, witnessed by all the very important people in this ritual.

Banten pejati is the medium in the form of the peseselan offering symbolizing Panca Dewata (the five manifestations of God; Brahma, Vishnu, Shiva, Iswara, and Mahadewa). The medium is used at the time of the performance of the God Witness (dewa saksi) ritual at a holy place (sanggah) of the bride's extended family. The offering consists of banten daksina, symbolizing God's mastery of the universe.

Tegteg is an offering to the one and only God as the creator, protector, and destroyer of the universe. It is to ask His permission to grant the marriage of the couple can last long or can stand firmly (enteg), is unshakable by any forms of challenges in life.

Ajuman is an offering to the one and only God in his manifestation as Sahyang Semara and Sanghyang Ratih (the authority of male and feminine light energy powers (purusa-pradana), which is considered as the seed of life. It is in the form of a ceremonial dish of white rice and yellow rice (tumpeng penek putih and tumpeng penek kuning), rice cake boiled in a rhombus-shaped packet (ketipat kelanan), ornaments of coconut leaves and flowers (canang), and local fruits.

Pengeluar nasi warna is an offering to the 5 Sang Kala (5 evil spirits) that are believed to occupy and, at the same time, keep the horizontal direction of the universe (north, south, east, west and the center). This offering is made of plain rice, red rice, yellow rice, black rice, and rice with a mixture of the four colors. Plain rice is an offering to sang kala petak, red rice to sang kala bang, yellow rice to sang kala jenar, black rice to sang kala ireng, and the mixed-color (berumbun) rice to kala tiga.

Canang penunasan is a medium of offering to ask for permission from God for taking holy water that has been blessed through the melehpeh ritual and is believed to contain the blessing and power from the one and only God. This holy water is sprinkled to the couple and those who participate in the ritual.

Peras is an offering presented at the end of a malehpeh ritual by the leader of the ritual, indicating that the malehpehan activity is over. In this case, the performer of the ritual withdraws, and the tearing of this peras by representatives (usually involving three tetuas) done by pulling the end of a young coconut leaf in the peras offering that is given by a spiritual leader leading the ritual.

Natab sayut is the ritual conducted at the bridegroom's house, specifically in a room named bale gede. The aim is unifying the bridegroom and the bride spiritually as members of the bridegroom's clan. It is done after the melehpeh activity. Through this ritual, both the bride and bridegroom are $\mathrm{c}$ to have united. The bride starts to follow the bridegroom's clan. This ritual is led by the temple priest of the bridegoom's clan. Through this ritual, the bride is also introduced spiritually to the bridegroom's ancestors, who have been stationed at the bridegroom's family temple.

Ngaturan piuning is a ritual done after the activity of natab sayut at the holy place (sanggah) of the bridegroom's extended family. It is done at the building for performing rituals, called bale piyasan. The aim is unifying spiritually the newly married couple as members of the bridegroom's extended family. Through this ritual, the newly married couple asks the one and only God and the ancestors to bless them with strength. The marriage can last long, and stay safe will be blessed with many children. This newly married couple's representatives attended the ritual. With the end of this natural pruning, the process of the ngidih marriage tradition is considered to be over.

Teenan is the offering used as the basis to complete the ritual media in case, after performing the ritual, there is still something lacking, such as something forgotten by the one who performs the whole wedding ritual. Teenan is made up of coconut leaves, rice, and coins. As a gift, the teenan goes to the spiritual person who leads the ritual. 


\section{Discussion}

The ngidih marriage tradition practiced in Bali is a rather complicated one, but it is the most popular marriage tradition practiced by North Bali community. This type of marriage is similar to the ones practiced in North Lombok, where it is called melakoq, that is to say, a type of marriage initiated by a proposal from a bridegroom's side to the bride (Muhammda 2018). This type of marriage ceremony is called deke teirum in West Sumba and latah hamam in South West Sumba. The merangkat marriage (elopement), is also similar to the one practiced in North Lombok, where it is named memulang, and in West Sumba, where it is named malengidinage; in South West Sumba it is called pakodong. Melegandang is married by force in North Bali community was popularly practiced in the past, but it is not practiced anymore at present. This type of marriage is named yoppa mawine in West Sumba and is termed (palagi pahahango) in South West Sumba. It has nowadays become unpopular in Bali and North Lombok.

The nyentana (a marriage type in which a family does not have a boy to continue the male line, and therefore invites a boy from another family to marry their daughter) is not recognized by North Bali community, but it is popular in South Bali. It also exists in West Sumba and named douna uma loka. This type of marriage is not familiar in North Lombok. In short, it can be said that the marriage system in every place is unique. Some of the systems are similar but have different terms.

\section{Conclusion}

Based on the discussion above, this study concluded; the whole ritual steps of the ngidih marriage consist of ngluku, mesedek, ngidih, mebiakala, natab kesurya, melukat pebersihan, malehpeh, natab sayut, and ngaturang piuning. Sixty-two lexicons were collected in this study. They are spread over the whole steps of the ngidih marriage. There are also some traditional symbols reflecting the Bali Hindu religion, namely, bantal alem, nyuh tingkih, peselan, peras, pejati pengrawas, pecanangan, sirih pinang, pamor, tembako gambir, and daksina, tegteg. Based on the cultural meaning found the lexicons, North Bali Community view that the bond of the bridegroom and bride is not only a matter of physical union, but also a spiritual one involving their interrelatedness to the rules of bridegroom's family, clan, traditional community, and the local government. For that reason, the ngidih marriage tradition is witnessed by three parties; bhuta saksi (evil spirits witness), manusia saksi (human beings witness), and dewa saksi (God witness). It has reflected in the whole steps of the marriage rituals.

\section{References}

Abdullah, W. (2013). Etnolinguistik: Teori, Metode dan Aplikasinya. Solo: Universitas Sebelas Maret.

Anggayana, I.A., Budasi, I.G., \& Kusuma, I.W. (2019). Social Dialectology Study of Phonology in Knowing English Student Speaking Ability. The Asian EFL Journal, 25(5.2), 225-244.

Anggayana, I.A., Suparwa, I.N., Dhanawaty, N.M., \& Budasi, I.G. (2020). Lipang, Langkuru, Waisika Language Kinship: Lexicostatistics Study in Alor Island. International Journal of Psychosocial Rehabilitation, 24(4), 301-319. doi:https://doi.org/10.37200/IJPR/V24I4/PR201010

Arniati, 1. ( 2013). An analysis of communication strategies used in 'Ngidih' wedding ceremony in Sawan Village. Thesis. Universitas Pendidikan Ganesha-Singaraja.

Aryani, I.G.A. (1983). Laporan Penelitian Tentang Hukum Pidana Adat Desa Tenganan Pageringsingan, Karangasem Amlapura. Denpasar: Penerbit Fakultas Hukum Udayana. 
Bora, Y.N. \& Purawati, N.K.(2018). Douna Uma Marriage Community of Kalebu Ana Kaka Village, Tana Righu District. West Sumba Regency. Mabasindo Journal, 2(2), Edition November 2018.

Budasi, I.G., \& Anggayana, I.A. (2019). Developing English for Housekeeping Materials for Students of Sun Lingua College Singaraja-Bali. The Asian EFL Journal, 23(6.2), 164-179.

Casson, R.W. (1981). Language Culture, And Cognition. London Collier Macmillan Publisher.

Chaer, A., \& Agustina. L. (2010). Leksikologi dan Leksikografi Indonesia. Jakarta: Rineka Cipta (n.d.).

Chaer, A. (2007). Linguistik Umum. Jakarta: Rineka Cipta.

Crowly, Terry. (1997). Introduction to Historical Linguistics. New York: Oxford University Press.

Darta, I.G.N. (2013). Times, Rites, and Festival in Bali. BAB: Publishing, Indonesia.

Denzin, N.K., \& Lincoln, Y.S. (Eds.) (2011). The SAGE Handbook of Qualitative Research $\left(5^{\text {th }}\right.$ Ed.). Thousand Oaks, CA: SAGE Publications.

Duranti, A. (1997). Linguistic Anthropology. Cambridge: Cambridge University Press.

Hassan, A., Kazi, A.S., \& Asmara Shafqat, Z.A. The Impact of Process Writing on the Language and Attitude of Pakistani English Learners. Asian EFL Journal, 27(4.3), 260-277.

Hestiyana, (2017). Leksikon Dalam Mantra Panawar (Kajian Etnodidin Sebagai Pengobatan Tradisional Masyarakat Banjar), Dalam Membaca Nusantara Melalui Bahasa, Media dan Pembelajaran, 351-361. Yogyakarta: UNY.

Kramsch, C. (1998). Language and Culture. Oxford: Oxford University Press.

Kridalaksana, H. (2011). Kamus Linguistik. Jakarta: Gramedia Pustaka Utama.

Kusuma, I.R., Osin, R.F., \& Anggabawa, I.A. (2019). Impact of Tourism Industry-driven Media Communication in Students' Speaking Ability. The Asian EFL Journal, 23(6.3), 27-45.

Masinambouw, E. (1997). Metodologi dan Pendekatan Budaya: Bahan Ceramah Loka Karya Terpadu Studi Indonesia Bogor.

Mbete, A. (2007). Ekologi Bahasa Bahan Matrikulasi Program Magister Linguistik PPs Universitas Udayana.

Muhammad, S. (2018). Leksikon Dalam Adat Perkawinan Masyarakat Suku Sasak di Kabupaten Lombok Utara: Sebuah Kajian Etnolinguistik. Jurnal Mabasindo. 2(2), 90-91.

Nirwani, I.I. (2018). Pandangan Hidup Masyarakat Sasak dalam Leksikon Nama Seseskan: Sebuah Tinjauan Linguistki Antropologi. Deskripsi bahasa, 1(2), Oktober 2018.

Ratminingsih, N.M., Budasi, I.G., \& Kurnia, W.A. (2020). Local Culture-based Storybook and Its Effect Reading Competence. International Journal of Instruction, 13(2), 253-268. Retrieved from http://e-iji.net/dosyalar/iji_2020_2_18.pdf

Riana, I.K. (2003). "Linguistik Budaya: Kedudukan dan Ranah Pengkajiannya", Pidato Pengukuhan Sebagai Guru Besar Tetap dalam Bidang Ilmu Linguistik Budaya Universitas Udayana. Denpasar: Universitas Udayana.

Sudaryanto. (1996). Metode dan Tehnik Analisi Bahasa: Pengantar peneltian wahana kebudayaan secara linguistik. Yogyakarta: Duta Wacana University Press. 
Sudiartini, N.K. (2018). An analysis of communication strategies used in 'ngidih' wedding ceremony in Sawan Village, Thesis. Universitas Pendidikan Ganesha-Singaraja.

Sudipa, I.N., Aryati, K.F., Susanta, I.P.A.E., \& Anggayana, I.W.A. (2020). The Development of Syllabus and Lesson Plan Based on English for Occupational Purposes. International Journal of Psychosocial Rehabilitation, 24(4), 290-300. https://doi.org/10.37200/IJPR/V24I4/PR201009

Suhenda, H., \& Yusep, A. (2014). Cerminan Budaya dan Identitas Lokal Dalam Leksikon Perpadian di Perbatasan Kabupaten Sumedang-Majalengka. Dalam Bahasa Ibu: Pelestarian dan Pesona Bahasanya. Bandung: UNPAD Press.

Supriyatno, T., Susilawati, S., \& Hassan, A., (2020). E-learning development in improving students' critical thinking ability. Cypriot Journal of Educational Sciences, 15(5), 1099-1106. https://doi.org/10.18844/cjes.v15i5.5154

Vardiansyah, D. (2004). Pengantar Ilmu Komunikasi: Pendekatan Taksonomi Konseptual. Ghalia Indonesia, Jakarta.

Wamalwa, E.W., \& Oluoch, S.B.J. (2013). Language Endangerment and Language Maintenance: Can Endangered Indigenous of Kenya Be Electronically Preserved? International Journal Humanities and Social Science, 3(7), 258266.

Wierzbicka, A. (1992). Semantics, Cultures, and Cognition: Universal Human Concepts in CultureSpecific Configurations. New York: Oxford University Press.

Toti, U., \& Majed, O.A. (2021). Cultural schemata and nativization of reading: I Wandered Lonely as a Cloud by William Wordsworth. Journal of Language and Linguistic Studies, 17.

\section{AUTHOR BIODATA}

I Gede Budasi is a senior lecturer of linguistics at the Foreign Language Department of the Faculty of Language and Art of the State University of Ganesha Education, (Fakultas Bahasa dan Seni, Universitas Pendidikan Ganesha) Bali, Indonesia. He completed his bachelor degree from the Faculty of Education of Udayana University, Bali in 1994, and hold a Post-Graduated Diploma in Applied Linguistics from the Regional English Language Center Singapore in 1990. He hold a master of education degree from the TESOL Program of the Faculty of Education University of South Australia in 1995. He was awarded Dr in Linguistics by the Faculty of Language and Humanity, Gadjah Mada University at Yogyakarta in 2007.

Dr. I Wayan Suryasa, S.S., M.Hum was born in Marga on July $5^{\text {th }}$, 1981. He is senior lecturer in STIKOM Bali, Department of Computer System, Denpasar, Indonesia ID 80226 Ph. +6281338734500. He graduated his bachelor degree in the Faculty of Letter, Warmadewa University in 2006. He finished his master degree in the postgraduate program, magister program, linguistic studies, Udayana University in 2014. He completed his doctoral studies in Udayana University in 20219. He was the founder of the Science Scholar institution in Tabanan. 